\title{
EL ADJETIVO VISUAL. DE LA FIGURA RETÓRICA AL SIGNIFICADO DE LA IMAGEN FOTOGRÁFICA
}

\section{THE VISUAL ADJETIVE. FROM RHETORICAL FIGURES TO PHOTOGRAPHIC IMAGE MEANING}

\section{AUTOR}

\section{Hernando Gómez Gómez}

Universidad Europea de Madrid/Universidad Complutense de Madrid (España) hernando.gomez@uem.es

\section{RESUMEN}

El giro conceptual que se produce en la últimas dos décadas en la disciplina visual, y en concreto la fotografía, deja entrever un cambio radical en el modo de percibir la expresión artística que hasta este momento se reconocía tradicionalmente como tal. Tal vez por ello comienza a asociarse una expresión que cada día más cercana a esta categoría fotográfica; "poesía visual".

Es entonces cuando esta denominación se ve afectada por el uso y abuso de la misma. La definición que ayudaba al espectador a introducirse aún más en el tipo de lenguaje, empieza a sentirse desorientado por la denotación ambigua.

Por todo esto es por lo que el proyecto empieza a tomar forma y a confeccionar una idea clara y multidisciplinar; La (supuesta) poesía visual recogida en la fotografía resultante en España en la última década podría deberse no tanto a un resultado casual sino más bien a un resultado (aunque inconsciente por parte del fotógrafo creador) propio de la lingüística e interiorizado históricamente por el poeta y literato. Desde este panorama, lo que se pretende es redirigir al lector visual o espectador hacia un camino adecuado y sin equívocos.

Y al mismo tiempo la poesía usará una serie de herramientas denominadas figuras retóricas, con las que se deberá confeccionar el significado poético. Aunque este no 
será el eslabón que unirá el propósito del fotógrafo-poeta y la investigación aquí planteada. En este estudio se dará un paso atrás, se fijará la atención en una estructura fija y anterior a la ya conocida (Figura Retórica), es decir, a sus precedentes (resto de palabras y signos de puntuación que confeccionan el lenguaje). En concreto con aquellas palabras que ayudarán en la definición, en la descripción. Que servirán para enumerar, para describir emociones. Se comportarán de forma rotunda y sin ambigüedades. Nos estamos refiriendo al Adjetivo.

El resultado obtenido servirá de herramienta completamente eficaz tanto para la confección artística de la obra con sentido poético, como para la enseñanza y labor docente de la disciplina artística.

Buscar una justificación concreta del porqué del proyecto, sería encontrar un novedoso lenguaje que fuese más rápido, más concreto y más eficaz desde el punto de vista de la producción poética.

\section{PALABRAS CLAVE}

Retórica - Semiótica - Lingüística visual - Poesía visual - Fotografía - PhotoEspaña.

\section{ABSTRACT}

The conceptual shift that occurs in the last two decades in visual discipline, above all in photography, suggests a radical change in the way of perceiving the artistic expression that until now it has been traditionally recognized like this. Perhaps it was the reason which gave to Photography an extra meaning and commonly called; "visual poetry".

But suddenly, this term is affected by the extra use and abuse. The definition that helped the viewer to penetrate further into this kind of language, begins to feel disoriented by the ambiguous denotation.

For all this reasons the Project was born in order to take shape and make a clear and multidisciplinary idea; The collection (supposed) of visual poems created in the last two decades in Spain, probably were created without any spontaneous sense, but 
rather it was following some parameters similar to Linguistic science (though unconscious by the photographer operator) and internalized by the poet and writer. From this background, the aim is to redirect the visual reader or viewer to a right ways and without misleadings.

And poetry uses a collection of tools (Rhetorical Figures) in order to complete the poetic meaning. Although this is not the link that will connect the purpose of the poet and photographer with the research raised here. This study takes a step back, paying the attention on a fixed structure and before of rhetorical figure. And if the words and symbols of punctuation used in the the lenguages are remembered and in particular with those words that will help to define, in descriptions, which use to enumerate, describe emotions, ... the adjective is likely to be spoken.

The result will help to create effective tool both for making art of the work with poetic meaning, as for education and teaching in the photography disciplina. This project was considered in order to go faster and farther in the process of artistic creation. In particular, in making photographic work with poetic sense.

\section{KEY WORDS}

Rhetoric - Semiotics - Visual linguistics - Visual Poetry - Photography, PhotoEspaña Adjetive.

\section{ÍNDICE}

1. Introducción

2. Presentación del Proyecto. Intención y entorno

3. Propósito y construcción del discurso. Docencia y Producción Artística

4. Fotografía. Construcción del concepto fotográfico: Perspectiva semiótica, retórica y psicológica.

5. La Fotografía y su significado

6. Figuras icónicas en la Fotografía

7. Construcción del concepto fotográfico 
8. Análisis metodológico para el estudio de la Fotografía

9. Análisis de la Fotografía desde la Psicología

10. Perspectiva Semiótica de la Fotografía

11. Fotografía y Adjetivo. Máxima expresión visual

12. Fotografía y PhotoEspaña

13. Conclusiones

14. Bibliografía

\section{Introducción}

Pocos momentos de reflexión hacen falta para darse cuenta del excesivo cambio que se está produciendo en los sistemas visuales tradicionales. La necesidad de crear nuevos registros ha obligado a los pensadores culturales a modificar los hábitos de conducta en el consumo de los medios de comunicación relacionados, ya que la imagen como el arte, nunca aceptarían un estancamiento de los modos expresivos conocidos, y sí dar rienda suelta a la nueva creación. Por ello es que de forma insospechada aparece una nueva promesa dentro del ámbito visual; la Fotografia. Pero...nos preguntaremos "¿La fotografía no nació ya hace más de un siglo?". Posiblemente así fue, pero lo que aún nadie se ha preguntado es si verdaderamente es la misma Fotografía que nació, aquella que aparecía bajo emulsiones de nitrato de plata sobre placas de cobre, 0 incluso las que resultaban de las cámaras estenopeicas. Pues por desgracia para los románticos del arte fotográfico se podría afirmar casi con rotundidad que en la forma; sigue siendo lo mismo, pero en el fondo; cambio de dirección absolutamente. 
La incorporación de las nuevas tecnologías afecta a la Fotografía de varias maneras. Siempre será polémica la discusión, pero la realidad viene a decirnos que ciertos modelos novedosos van a afectar al sistema visual.

Desde que la fotografía se incorpora a nuestras vidas, y por vidas vamos a entender nuestro momento diario, lo que acostumbramos a ver y palpar, aquello que deja elimina el factor sorpresa para finalmente ser adquirido por un público deseoso de progreso, parece ser que es cuando se produce ese verdadero cambio. Robert Capa aparece en escena con una fantástica Leica capaz de retratar el movimiento más duro de una guerra, siendo tal vez uno de los pasos más importantes de la fotografía aun sin saberlo.

¿Cuál es la diferencia que existe entre aquellos que fueron retratados para perdurar en la historia y quienes ofrecieron un punto de vista determinante para entender las diferentes sensaciones? Pues precisamente este será el punto desde el que partiremos para entender qué es lo que contendrán mis palabras a lo largo de este escrito. Resumiré la inserción de la Fotografía en las esferas del arte, y diseccionaré ésta con el fin de encontrar el elemento clave que sirvió en su día como fuente de inspiración creadora.

Sin embargo realizar un análisis de los últimos cien años de la fotografía resultaría tan complicado como absurdo. Por ello es que vamos a centrarnos en lo más cercano; la última década. ¿Qué es lo que se produce en este periodo? Durante los últimos años estamos experimentando una nueva evolución dentro de la fotografía que nos va a ofrecer una ventaja añadida con respecto a las "Fotografías" que ya conocíamos.

Desde hace algunos años me ronda por la cabeza la necesidad de descifrar ciertos asuntos referentes a las magníficas obras fotográficas que podemos observar, donde 
insisto en enfatizar que por magníficas obras fotográficas entiendo cualquier pedazo de realidad fijado en cualquier soporte, perteneciendo al elenco principal: la fotografía vinculada con el arte, la fotografía publicitaria y la fotografía cinematográfica.

En estas tres desviaciones de la primera fotografía donde simplemente se retrataba a un ser, podemos decir que se encuentra un verdadero carácter poético. Podemos extraer sensaciones, crearemos necesidades, invadiremos universos de significación y lo más importante; nos trasladaremos de donde estamos.

¿Cómo es posible que un instrumento tan pequeño pueda convertirse en algo tan grande? Con razón podemos intuir que la imagen fotográfica es ya parte de una era bautizada como visual, donde la decodificación de símbolos nos resulta mucho más sencillo que descifrar la esencia de las palabras. En el caso de la publicidad esta ha decidido adherirse a este nuevo concepto y no adquirir nunca más las tradicionales estrategias de venta. ¿Por qué? Porque el "cliente potencial" necesita ese factor sorpresa del que previamente hablábamos. Quiere y desea asumir ciertos roles que siempre había soñado, pretende escuchar sus carencias para así subsanarlas de una vez por todas...

Resulta un tanto paradójico todo este despliegue de "teoría etéreas" sobre algo tan banal como un agente comercial. Sin embargo resulta tan gráfico para explicar mis estudios que es necesario agarrarse a referencias cercanas para así comprender el momento que hoy vivimos en la Imagen fotográfica.

Por un lado aceptamos que el arte considera ciertas impresiones y emociones inherentes a la propia obra en sí, entonces si el arte acepta este punto importante como requisito imprescindible para la admisión o no de cualquier otra disciplina, ¿qué le ocurrió a la Fotografía para ser tan afortunada en su reconocimiento? 
Son demasiadas preguntas las que aquí se plantean y aún no se ha desvelado la verdadera esencia de la línea de investigación. Pero lo cierto es que la imagen "más valorada" en el área artística debe poseer a la fuerza elementos similares a los de la escultura, a los de la pintura, a los de la literatura,...y ¿por qué no?...a los de la poesía.

Por ello es que mantendremos ésta tesis en la que las herramientas que ayudan a la construcción poética deberán serán perfectamente ajustables a cualquier otra disciplina estética y pura.

Y ahora es donde entra en escena la fotografía de los últimos diez años, concretamente podremos observar que se da un viraje hacia lo desconocido, poético y tal vez cercano a lenguajes oníricos. Se podría decir que ya desde hace algún tiempo las imágenes culturales más relevantes e innovadoras no paran de sorprender al acreditar un verdadero carácter lírico, lleno de simbolismo, y con explicaciones implícitas de una sensibilidad arrolladora y excepcional, tal vez con la finalidad de gozar de reconocimiento en esferas intelectuales de enorme importancia.

Sin embargo la realidad viene a decirnos que ese carácter poético y bucólico trae tras de sí un gran recorrido semántico, sintáctico, fonológico y estructural, donde la casualidad del símbolo desaparece para dar lugar a estructuras fijas ya conocidas y con grandes efectos pretendidos por parte del mensajero creador o artista en definición.

Estamos hablando de la figura retórica como recurso literario más importante para poder entender el sentido más mágico de nuestro discurso, siendo tanto lingüístico como visual.

Y teniendo en cuenta lo arriba mencionado, importante para apoyar y entender lo que estoy por expresar con respecto al discurso implícito que toda obra debería traer tras de sí, es importante puntualizar la fuerza y el impacto tan inmediato que estas 
imágenes poseen de modo intrínseco. Ya desde sus primeros momentos, aunque manifestándose más claramente desde que la fotografía y la imagen trabajan en nombre del arte, la figura literaria está precedida de estructuras mucho más simples, tales como el monema, morfema y ya como unidad mucho más firme; la palabra. Aunque verdaderamente de igual o mayor importancia que la figura retórica debido a su especial habilidad para recomponer a través de sus mismos símbolos, cierta coherencia discursiva que nos introducen como resultado final en nuestra obra.

Sin embargo esta vez nos vamos a decantar por un tipo de palabra en concreto. Aquella que acompaña al sustantivo, sea o no concreto, sean o no abstracta. Un tipo de palabra que servirá para especificar características, que se obtendrá como adyacente y coincidirá en género y número. En ocasión no será necesaria esta coincidencia aunque sí el número y en otras se apocoparán (desaparición de uno o varios fonemas).Admitirá afijos y morfemas de grado superlativo. Además, a su definición y capacidad descriptiva se le sumarán el carácter comparativo, de superioridad, de inferioridad...etc.

Me estoy refiriendo al símbolo que precede a nuestra capacidad analítica, que sirve como instrumento para designar a nuestra obra poética creadora, que estimula nuestro intelecto para redefinir obras externas y creaciones que nos conmueven con un solo fin; materializar lo que invade nuestro pensamiento al enfrentarse a un discurso. Me refiero al poder del ADJETIVO como elemento referencial para confeccionar las bases de nuestra obra reflexivo-visual.

Sin embargo lo que resulta interesante del adjetivo es su posición previa antes de llegar a la figura retórica y a su vez, ésta misma al contenido poético. Sintetizando; es imposible encontrar poesía sin figura retórica, y mucho menos confeccionar recursos estilísticos sin adjetivos. Por lo que si esto verdaderamente sucede en la naturaleza poético-narrativa, a la fuerza deberá también darse el mismo caso en lenguajes visuales. 
Pero la duda que me surge una vez más, pensando siempre en mi "background" de imágenes que manejo a diario, es si realmente esa poesía implícita la encontraremos en la fotografía que hoy se considera relevante en su significado, destacado y de carácter superior.

Por ello es que, en primera instancia se centrarán todas las energías en la imagen fotográfica de la última década para poder encontrar y determinar ese componente poético (siempre que lo hubiese), recubierto por una esfera retórica como si de un poema literario se tratase, localizar el recurso o los recursos estilísticos aplicables en poesía además de la adaptación visual que se ha necesitado para dar un énfasis pretendido con anterioridad. En segundo lugar, y convirtiéndose ésta en el pilar que sostendrá la investigación, el punto de mira se focalizará en la descripción adjetival o atributo delineado que propondrá el espectador, entendiendo ésta como la visión más crítica del arte.

\section{Presentación del Proyecto. Intención y entorno}

En esta sección se tratará de ahondar en las diferentes disciplinas que en esta en este trabajo de investigación interactúan, aclarando que ninguna actuará con un rol de mayor importancia con respecto a otros, y avisando previamente que la interdisciplinaridad que aquí nos encontraremos, de algún modo será parte de una reflexión muy meditada y sobre todo sección fundamental de la filosofía del proyecto.

Se comenzará especificando cuáles serán las disciplinas y sus "quehaceres" dentro del trabajo de investigación. Las doctrinas que necesitarán unas de otras para poder existir y verificar las cuestiones que se plantean, es necesario que existan para poder conocer los efectos en el espectador u observador de las obras fotográficas aquí propuestas. Estás serán: 
- Fotografía: la imagen fotográfica, como bien se especifica en la introducción, está sufriendo un continuo proceso de variación, ya desde su primer momento o aparición. Sin embargo, en cuanto a temática o focos de atención se refiere, ha perdurado en el tiempo prácticamente sin mudanza. Su carácter gráfico-documental siempre ha supuesto su punto más fuerte, junto con su gran componente realista que acompañaba a las noticias de todo el mundo y a los historiadores que pretendían mantener en la eternidad una serie de hechos y acontecimientos. Lo cierto es que ya desde sus más lejanos orígenes los artistas miraron a la fotografía como si de un pincel sobre un lienzo se tratase. Llega el siglo XX y es un momento excepcional para innovar libremente. La fotografía comienza a obtener unos resultados maravillosos en la vanguardia artística, y es entonces el momento que exagera su cambio de dirección, y además sin que cayera en el olvido el impacto que ya tenía en los medios gráficos y prensa escrita. Aquí será donde precisamente hallaremos el carácter detallado que únicamente nos interesará de la Fotografía.

- Poética: Desde el momento que los artistas cogen de la mano esta técnica física capaz de capturar momentos, de alguna manera están haciendo partícipe a la fotografía de una actividad que logrará modificar significados, que entenderá de sentimientos y de momentos de inspiración de los autores que así la utilicen, que provocará reacciones de los espectadores y que suscitará recuerdos y experiencias de todos aquellos que observen.

Pues bien, si todo esto se produjo ya casi hace un siglo, y teniendo en cuenta que el fin de los artistas con la fotografía no era simplemente documentar, plasmar o materializar su obra pictórica, escultórica, etcétera...se podría afirmar que comenzaba a generarse un sentido poético de la imagen visual tomada con una cámara fotográfica. Y poético desde el punto de la belleza, de la armonía de las formas, de la necesidad de expresar sensaciones engendradas por elementos sensoriales; por la vista. Poética desde el punto de vista del envolvimiento de los elementos que en ella aparecen y con el fin de encontrar sentidos definido por sus creadores. Pero siempre siguiendo los cánones de la poética, entendida como disciplina del buen discurso y del 
bien hacer de las cosas. Con sus mismas estructuras y características. En definitiva; de la virtud de la imagen.

- Retórica: Esta disciplina que bien se extendió en el pensamiento filosófico de la antigua Grecia (Aristóteles, Platón o Isócrates), se centraba en la idea del buen orador, de quien se dirigía a un público deseoso del saber y de la verdad. Armas de doble filo donde las hubiera, pero usándolos del modo adecuado tanto orador como oyente sentirían un fuerte deseo de actuar, de tomar, de necesidad, etc.

La Retórica consta de las técnicas del bien hablar para conseguir efectos predeterminados; la persuasión. Usándose ésta no en término peyorativo o peligroso, sino más bien abogando por la no existencia de la verdad absoluta, y sí de la exposición de argumentos que convenzan a quien los escuche. Esta ciencia además cree en la poética como si de un "aliado" se tratase, ya que desde entonces hasta hoy ambas actuarán en un mismo modo. Siendo la belleza del discurso y sus modos de actuación, su "modus operand". Entonces será la figura retórica o recurso estilístico el que verterá una belleza formal y estudiada. Se precisa una regla formada, siempre con el fin de encontrar más belleza.

- Lingüística: El poder de la palabra es la máxima expresión de todo lo mencionado anteriormente. Conocer sus reglas y excepciones harán, a quienes las posean, sabedores de un poder absoluto capaz de dirigir miradas.

La lingüística es la madre y ciencia de la lengua, y como tal ofrecerá trasladar sus mismas reglas hacia lenguajes desconocidos como las artes. La lingüística es lógica pura, como cualquier sistema que se precie, y por ello ¿Por qué no trasladar esta lógica formal a la fotografía con el fin de obtener resultados absolutos?...Además, en ella contenida tropezaremos con todos sus elementos y variantes. Desde las palabras a los adjetivos, adverbios, sustantivos, verbos, etcétera... 
- Adjetivo: Con él, se encontrará el modo de definir lo que observamos, darle un grado más o menos intenso, podrá ser percibido por todas partes, como si de un texto o discurso se tratase. Pero con más relevancia; la que se merece. Sentir el poder de la palabra adjetivada dentro de la imagen fotográfica de la última década y propuesta por el certamen de PhotoEspaña, será el verdadero y primer propósito.

La preferencia por el adjetivo se produjo tras encontrar algo diferente en él (con respecto a las demás formas lingüísticas).Este goza de rotundidad. No engaña a nadie ni se hace ambiguo. Aunque básicamente por una razón simple; sin su existencia, no habría matices en la expresión hablada.

Sin que caiga la FOTOGRAFÍA en el olvido, se puede decir de ella que tras observar imágenes con carácter poético, lo que se produce es una sensación de estímulos provocados por emociones enormes, sublimes, que nada hace presagiar se refieran a los convencionales elementos que se entremezclan, para conseguir la belleza de un familiar o paisaje cualquiera. Es un estado de catarsis comparado con la emoción provocada por tus experiencias de vida, aquello que te hace emocionar.

Es entonces cuando se deduce lo esencial de la fotografía. Que por otro lado no se trata de fotografías convencionales, sino más bien imágenes concebidas para ello mismo; para provocar y recibir lo ya experimentado. Lo esencial de lo ya vivido tendrá como resultado un producto en forma de "estado", provocado por un leguaje que al parecer tiene todos los elementos necesarios para concebir lo mismo que el poeta a la poesía. Por lo que será aquí cuando se dejara visible aquello que tal vez un día afortunado se bautizó como "poesía visual".

\section{Propósito y construcción del discurso. Docencia y Producción Artística}


Este lenguaje empleado por la fotografía se mueve por cierta tendencia variable. Nada es casual y tal vez hoy se dé el momento más rico, en cuanto a poesía visual se refiere. Por lo que, con el fin de acotar el universo de estudio, el punto de partida será un referente muy importante a nivel nacional e internacional como pueda ser PhotoEspaña. En él se observará cierta tendencia abundante hacia la creación de poesía a través de una o unas cuentas imágenes dispuestas de un modo concreto con un fin muy marcado, de cara al espectador-ojeador- "visionador" o receptor de los conceptos aquí bien explicados. PhotoEspañá acoge grandísimos fotógrafos a lo largo del año, y el premio que otorga en la categoría más importante siempre recaba la atención de la audiencia debido a la originalidad de su expresión y por la trayectoria de su autor. En ella se observa, o al menos en la última década, cierta propensión a la belleza de la imagen con significado. Y atención que por "belleza" no se entiende lo más bello, sino a lo ordenado, a lo bien dispuesto, al tecnicismo puro y duro de la técnica fotográfica, etcétera...Lo bello también incluye lo feo, lo absurdo, lo abstracto. Al menos en la definición que habitualmente se maneja.

En la mayoría de estas imágenes se darán significados ocultos que se ofrecen a partir de mil recursos. Unos ofrecen oposición cromática, otras exageraciones de la imagen, otras tratan el costumbrismo y a veces desenfoques imposibles. Pero todos tratan de decirnos algo a través de la belleza visual...y es así como lo percibimos. La clave residirá en cómo se forma, cuáles son las herramientas que el fotógrafo tiene para aportar estos datos estéticos y cuál es el propósito del autor.

Por lo tanto el objeto principal de estudio se centrará en Encontrar o localizar los elementos utilizados, entendidos como herramientas (adjetivadas) que interactuarán en la confección de poesía visual. Es decir que se formalizará cada una de estas para facilitar la futura función del fotógrafo-poeta. Y conociendo las figuras retóricas que utilizan los poetas literarios para embellecer el mensaje y el lenguaje, trataremos de unificar la figura de este mismo, independientemente del formato que maneje. 
Como última instancia, aunque no menos importante, el eslabón que definirá la confección del recurso estilístico y por consiguiente el significado poético visual, será sin ninguna duda la existencia del adjetivo dentro de la imagen. Ya que la unión de partes mínimas dotadas de significado constituirán un sistema más complejo, como una figura retórica por ejemplo, para así detallar la belleza desde lo particular hasta llegando a lo general.

En todo proyecto de aclaración o verificación debería existir un apartado donde se ofreciesen los porqués de su existencia. Por esta razón se cree conveniente pormenorizar la necesidad de ciertas herramientas que ayuden tanto al proceso creativo como también docente. Que ponga en funcionamiento la máquina de elaborar imágenes, que dote a las imágenes (siempre hablando en calidad de fotógrafo) de la fuerza y del impacto necesario para dejar bien asentado el discurso de la obra. Tal vez reconocer esas figuras retóricas, constituidas a partir del adjetivo en su definición, ayudarían a la elaboración de la imagen final. Materializar "matices" finales en fotografía como ya hizo la lingüística tiempo atrás, se considera oportuno y tal vez ayudaría a su creación, ya que de este modo se conseguiría trabajar en una dirección muy concreta y definida, con una finalidad de mensaje clara ya a priori.

Y qué mejor modelo de aprendizaje para la enseñanza de esta disciplina que dejar bien asentado ciertas conductas de actuación que el alumno debería aplicar de modo automático para conseguir resultados sorprendentes aunque ya establecidos. Por lo tanto este modelo planteado no perdería la magia de la creación sino que simplemente apoyaría el énfasis retórico con un fin marcado ya a priori y sobre todo utilizando una lógica de resultados, propia de las matemáticas, de las lenguas, y por qué no, también para la poética implícita dentro de las imágenes.

Es decir que la justificación tendrá dos vertientes bien diferenciadas. Por un lado nos encontramos la eficacia de la materialización de estas teorías retóricas con un fin 
artístico, donde la complejidad de la obra en cuanto a su significado poético se refiere, podría verse beneficiado en cuanto al modo de plasmarlo. Es decir si el fotógrafo poeta o poeta visual conoce los medios para representar dolor, pasión, contrariedad, frialdad,...entonces enfatizaría de un modo más fiel si siguiera o continuara con las reglas retóricas que precisamente ayudan a representar lo que desea plasmar. Y por otro lado, la eficacia de conocer precisamente esta materialización, donde se le ponen nombres y apellidos a cada una de las herramientas retóricas, ayudarían también al docente de fotografía en el ejercicio de enseñanza de la disciplina con fines ya no sólo técnicos sino artísticos y de representación.

\section{Fotografía. Construcción del concepto fotográfico: Perspectiva semiótica, retórica y psicológica}

Es necesario hacer una distinción previa o aclaración de la cuestión, en cuanto a la temática u objeto principal se refiere, debido a lo multidisciplinar del objeto de estudio y la imposibilidad de separación, ya que jamás podría concebirse este estudio si no entran en la línea de juego las diferentes enseñanzas.

Posiblemente esta tendencia a denominar las cosas como a uno le parece hace que sea obligada una búsqueda exhaustiva del origen del fenómeno, y por ello es que sería escaso explicar la cuestión desde un solo ámbito. Hablar de fotografía sin apreciar su lado más técnico o más físico resultaría perderse la esencia que verdaderamente la hizo nacer. 0 hablar de poesía sin hablar de Retórica sería omitir la importancia de lo bello y el porqué de ésta. Es muy importante esta sección en la que se definirán ya no sólo las disciplinas, sino también todos los demás pilares involucrados en que exista esta imagen bella llena de significado, para así poder entender cuál era su situación en el pasado, cuál y dónde se encuentra hoy, para finalmente mirar hacia el futuro optimista de esta bella y novel disciplina artística, y en qué posición nos la encontraremos. 
Es necesario comenzar desde la mínima expresión y dónde se encuentra el origen de todos los elementos estéticos, para arribar en una cuestión más complicada de abstracción.

\section{La Fotografía y su significado}

La imagen fotográfica, ya desde su primera aparición, fue considerada una importantísima y mágica herramienta de significación. Pocos son los trabajos 0 estudios que han centrado su investigación en el significado y análisis de los objetos icónicos que se hallan contenidos en las imágenes fotográficas, sin embargo es innegable la capacidad significativa que hoy en día se maneja en la disciplina visual, que un día supuso una verdadera amenaza figurativa para los maestros pictóricos, debido al acercamiento de esta con una realidad muy próxima. Si pudiese hacerse una afirmación rotunda sería; "las imágenes fotográficas son verdadera unidades de sentido en las que se contiene una significación específica incuestionable".

La sección más relevante será por lo tanto aquella que se refiera a la capacidad de atributo de la fotografía, y en concreto en el aspecto narrativo y lectura implícita.

A día de hoy se sigue contemplando el debate referente a la inclusión de la fotografía en el área de las artes o si por el contrario es una potentísima herramienta utilizada en una cultura de masas, donde se ve alimentada por el bombardeo constante de imágenes que van modificando la conducta de los seres humanos. Posiblemente si se plantease la cuestión a un comité de expertos, seguramente que en pocos casos se aceptaría agruparía la fotografía dentro de las disciplinas que componen el Arte.

Esto seguramente se debe a una cuestión histórica; la fotografía ya desde su primer momento de vida se comportó como un elemento referencial, de evidencias, de realismos,...sin ir más lejos podemos observar como la fotografía Valle de la sombra 
de la muerte de Roger Fenton, tomada durante la Guerra de Crimea (1855), y tal vez una de las primeras que se tomaron en conflictos bélicos.

Aquí se puede observar como el momento de la toma ha sido seleccionada, es decir no consideró la captura de la imagen como un simple disparo de la cámara sin más. Consideró de especial relevancia seleccionar los elementos que entrarían a formar parte del discurso visual que aquí se trataría, eliminando aquello que no le interesaba y centrándose en los aspectos más simbólicos de la escena. El resultado sería el valor poético desde el momento que discrimina los cuerpos de las víctimas, para ofrecer el factor "sorpresa" y las encrucijadas que escondería un conflicto, a través de decenas de "balas".

Aquí se esbozan por lo tanto una serie de dudas que seguramente podrán ofrecer alguna pista de lo que se podría considerar significación en la imagen; por ejemplo el original punto de mira del fotógrafo será determinante para conseguir el valor de representación que pretendemos encontrar. En el caso del fotógrafo Bill Brandt, aparece un estudio del desnudo completamente sugerente e innovador tanto para el contexto en el que se encontraba, como para día de hoy.

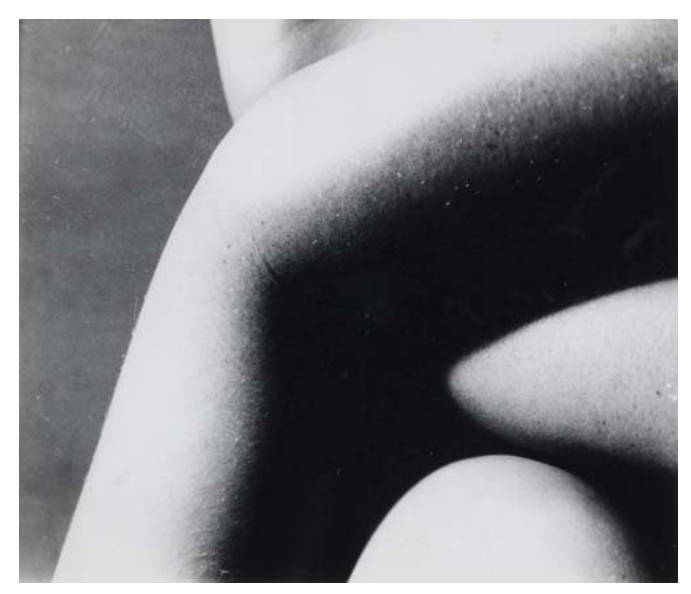

Se observa una plasticidad asombrosa, donde las formas se rinden a las sombras y las luces, siempre en sintonía con un primer plano que esconde un misterio; el cuerpo desnudo. 
Surgen infinidad de preguntas, pero la realidad adquiere un modo de trabajo exquisito, tal vez no tan novedoso hoy en día como lo pudo ser hace casi ya un siglo, pero de suma delicadeza y armonía con la disciplina visual que lo retrata.

Un segundo aspecto, no menos importante sería la artisticidad prestada de otros medios de expresión. En este caso se presenta como modelo una fotografía de Oscar Gustave Rejlander Las dos vías de la vida (1857), en armonía y sintonía con la actualización de la obra de Rafael La escuela de Atenas.

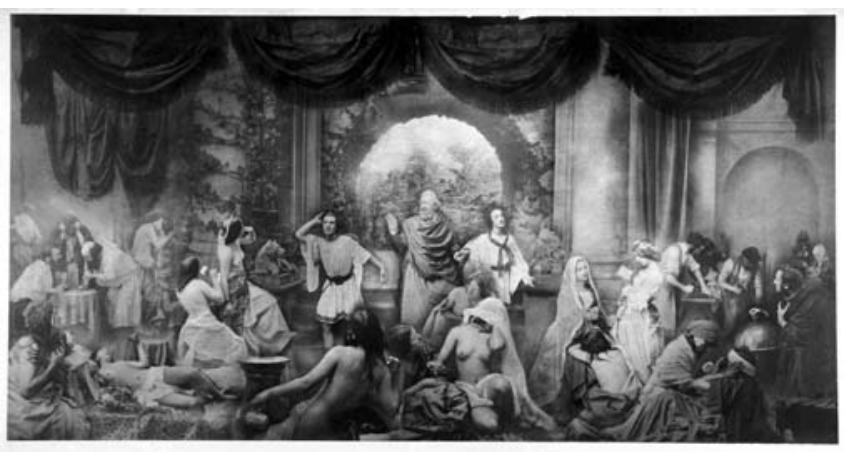

G. Rejlander

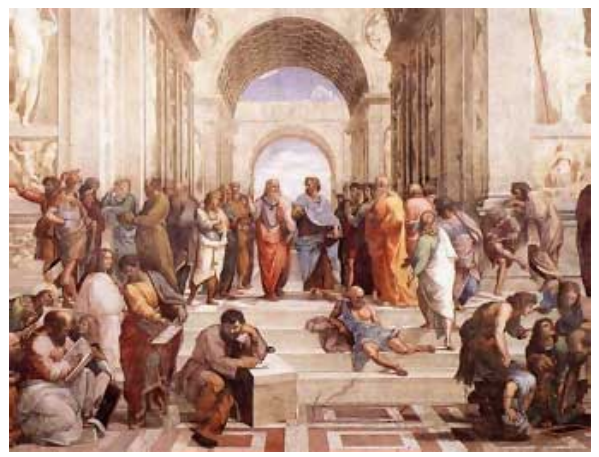

Rafael Sanzio

Aquí surgen dos disciplinas que difieren en cualidades técnicas y en referentes pictóricos. La intención de la fotografía de Rejlander es recrear la escena de Rafael, aunque jamás con carácter imitativo, sino representacional. Existe una adaptación de la obra fotográfica con el fin de acercarse al maestro pictórico.

Otro de los aspectos interesantes para poder entender el verdadero valor simbólico de la imagen sería algo que se encuentra en un terreno de estricta subjetividad; La seducción que transmite una obra fotográfica.

Es posible que al enfrentarse a cualquier tipo de obra artística, de repente y $\sin$ encontrar cierta explicación objetiva, surja la fascinación de la obra. Este es un hecho natural e intrínseco al ser humano, donde la sensibilidad estética actúa sin 
más, donde la atracción por los elementos observados se hará patente. El momento más interesante de este proceso será el referido a la capacidad de suscitar una reflexión del ser, para conseguir que se esboce una sonrisa o como el reconocimiento por parte del espectador de representación de la realidad.

Por lo tanto podemos hacer una síntesis de lo mencionado con respecto a la significación en la fotografía dando por sentado ciertas características comunes que se presentarán en las artes visuales. Siendo;Valor poético, Originalidad, Novedad, Sugerencia, Artisticidad, Valor metafórico, Fascinación, Emoción y Reflexión.

Si encontramos varias de estas, posiblemente se esté frente a una imagen fotográfica con cierta tendencia a la significación poética.

Pero si lo que verdaderamente importa es el análisis de las imágenes fotográficas, tal vez con el fin de encontrar una serie de características comunes que más adelante nos ayuden a construir el propio discurso visual, es importante afirmar que existen bastantes estudios dedicados a la naturaleza de la fotografía, donde seguramente se debería mantener el conocimiento de estos, siendo de este modo mucho más rigurosos en el estudio.

En 2004 se presentó en el Congreso "Teoría y Técnica de los medios audiovisuales" una metodología para el análisis del texto fotográfico ${ }^{1}$, dejando bien asentado que lo primero que se debe tener en cuenta es el carácter subjetivo del investigador frente a la obra fotográfica, aunque debiendo subsanarlo al máximo para dotar con el mayor rigor posible.

En un primer vistazo se tiene que reconocer ciertos datos interesantes para el análisis como el nombre del autor, fecha, movimiento artístico al que pertenece,... con este primer vistazo se construirá un universo listo para un análisis más profundo.

\footnotetext{
${ }^{1}$ Disponible en web: www.analisisfotografia.uji.es/root2/tecnico.html. Capítulo 2.1 Parámetros técnicos [Consultado el 12 de Abril 2010]
} 
Pero para la descripción más exhaustiva existirá un segundo punto de vista más riguroso donde se aprecie una neutralidad y desapasionamiento del investigador. Para ello se abordarán otras características más precisas como; si se trata de fotografía en color o blanco y negro, formato de presentación (35 mm, Medio formato, gran formato) con tamaño incluido $(36 \times 24 \mathrm{~mm}, 6 \times 6,9 \times 12 \mathrm{~cm}$...), tipo de cámara, soportes, objetivos,... sea decir, todo lo que tiene que ver con los metadatos de la imagen.

Y ya por último tener conocimiento de quién es el autor de la imagen retratada y el año en que fue tomada.

Es importante volver a expresar el aspecto de la fotografía que más interesa, para dejar bien asentado quién o que será el centro de interés; en este caso un tipo de fotografía con cierto componente poético y artístico, que maneje las directrices de las artes antes mencionadas y que por supuesto contemple todas las características necesarias para un análisis digno, con el fin de conseguir mayor complejidad formal y conceptual.

Si se tuviese que especificar el porqué de esta elección sería porque básicamente es sorprendente observar que aún a día de hoy se aprecia cierta tendencia al rechazo semiótico ${ }^{2}$. Sin embargo no se puede negar que al utilizar expresiones del tipo "lenguaje fotográfico" o "expresión visual", lo que verdaderamente se observa es una evidente identidad oculta que remite a la semiótica.

\section{Figuras icónicas en la Fotografía}

Se está viviendo un momento especial para las artes, debido al intrusismo e irrupción suscitado por los medios de comunicación. Los valores artísticos se han visto

\footnotetext{
2 GARRONI, E (1975): Proyecto de Semiótica. Editorial Gustavo Gili. Barcelona
} 
alterados por esta razón y la verdadera solución es observar, reconocer cómo actúan y aprender a convivir con ellos, a pesar de que una cantidad considerable de estudiosos, académicos, artistas e intelectuales han rechazado este fenómeno desde el principio.

Umberto Eco se atrevía a afirmar que la cultura de masas es anticultura.

Sin embargo no se puede negar la evidencia; la fotografía entendida como elemento perteneciente a esa cultura de masas y por lo tanto observada desde un punto de vista general, posee un inmenso carácter veraz y que además inauguró la era de la reproductibilidad técnica ${ }^{3}$, dejando tanto a historiadores de arte como de comunicación una labor informativa mucho más cómoda, precisa y visual.

El arte es algo intrínseco a la condición humana y desde luego es una de las necesidades más importantes que se ha creado. El arte considera a su entorno, lo que le circunda. Se relaciona con los humanos, ya no sólo como elemento presencial sino como elemento referencial. Posee un carácter antropológico y prueba de ello es la presencia inmediata de las artes en cada cultura individual por pequeña que sea.

El grado de abstracción de las artes ofrece una clara visión de esa cultura, donde se irán desarrollando herramientas cada vez más sofisticadas para la explicación de todo fenómeno ocurrido y sin explicación. La materialización de esas figuras ayudan a narrar esas experiencias, a que perduren en el tiempo, y sobre todo dejando espacio para la difusión del mensaje o simplemente la narración de los hechos.

Y como bien se afirma, el arte se crea como necesidad para convivir con el ser que le rodea, uno de los problemas que más debates suscitan en cuanto a la naturaleza del mismo será el de la intencionalidad. Es decir, se cree en la asociación directa de la

\footnotetext{
${ }^{3}$ MARZAL FELICl, J (2010): Cómo se lee una fotografía. Cátedra. Madrid 2010. Pág. 28.
} 
obra artística, y por lo tanto fotográfica, con la necesidad de expresar algo. El autor de la obra necesita transmitir cualquiera de las sensaciones que le suscita la creación.

A su vez hay ciertas teorías que afirman que el arte debe poseer a la fuerza dos rasgos determinantes; la indeterminación y la autorreflexibidad ${ }^{4}$. Es decir, en el primer concepto se pretende dar un carácter abierto y ambiguo de la obra fotográfica, dejando vía libre a la interpretación de la misma. La autorreflexibilidad ayuda al carácter reflexivo de la imagen proyectada, además de la configuración previa e interna de ésta. Estando en continua vinculación con la intertextualidad, es decir con lo que se encuentra dentro del texto y de su significado. El espectador debe tener en cuenta que la imagen que observa contiene un mensaje implícito mucho más rico que el que experimentan sus propios sentido, viéndose obligado por ello a descifrarlo.

Qué sucede con la primera aparición fotográfica?... seguramente, y al margen del factor sorpresa experimentado por una sociedad deseosa de tecnología, se vivió cierto recelo en las esferas del arte. La fotografía ofrece a priori un modo de abordar la reproducción y la representación como nunca vista, llegando a rozar la mímesis artística. Los artistas veían sus días contados ya que el problema de la figuración acababa de ser resuelto. La realidad estaba muy lejos de cumplir este objetivo.

La segunda amenaza de la fotografía fue ser la responsable directa de otros muchos inventos que cambiarían el modo de observar de los humanos; La cinematografía y la imagen electrónica.

Si verdaderamente la fotografía tuvo este carácter inaugural, podemos imaginar la influencia que ésta supuso en las esferas artísticas contemporáneas.

\footnotetext{
4 ECO, Umberto (1989): La estructura ausente. Introducción a la semiótica. Traducción Francisco Serra Cantarell. Editorial Lumen. Barcelona.
} 
Para empezar el arte desde un principio se vio bastante reacio a la aceptación de la fotografía como una de sus disciplinas. Y esta escasa atención se debió en gran medida a un factor relevante; se diferenciaba del resto de las artes tanto en cuanto a su carácter manual.

Pero si observamos cómo se desarrollaron los primeros trabajos fotográficos podremos observar como siguieron una línea muy similar al de la pintura, siendo además quienes la constituyeron verdaderos artistas o al menos así se sintieron ellos.

Como aspecto negativo; el negocio de tanto y tantos artesanos de la imagen propiamente dicho se fue al traste. Gran número de litógrafos y grabadores se vieron perjudicados en primera persona, tal vez comparable a la crisis que se vivió en la cinematografía al introducir el cine sonoro y dejando sin empleo a los músicos que llenaban espacios vacios con sus notas en las salas al proyectar las escenas mudas.

Pero en oposición a lo arriba mencionado, en el terreno docente y cultural la fotografía ha dejado grandes evidencias de su gran ventaja gráfica. Pronto se convierte en una herramienta de conocimiento, dejando a los espectadores de cualquier parte del planeta la posibilidad de observar obras de arte inéditas y jamás vistas. La fotografía posee la capacidad de la rápida difusión y de reproducción.

Se debe ser considerado con las artes, al igual que ellas lo son con las personas. $Y$ nunca desmerecer su verdadero carácter; referencial y poético. Existe una frase que bien lo define el arte fotográfico en calidad de institución museal parece oscilar permanentemente entre el documento y el monumento 5 .

\footnotetext{
${ }^{5}$ SCHAEFFER, J.M. (1990): La imagen precaria: del dispositivo fotográfico. Traducción de Dolores Jiménez. Cátedra. Madrid. Pág. 118.
} 
Esta capacidad analítica hay que tenerla prácticamente por defecto, sin embargo no corresponde con algo innato, es algo mucho más fácil de entender; el gusto está determinado por lo que nos circunda, por nuestras experiencias, por los gustos políticos y por los gustos de la época. Por lo tanto no será algo inexplicable sino aprendido (Gisele Freund).

Por ello es que se propone la imagen fotográfica como algo no simplemente artístico sino más bien como un hecho social. Debe ser analizada desde un punto de vista sintáctico (como si de un sistema lingüístico u otro cualquiera se tratase), desde un punto de vista semántico (Perteneciente o relativo a la significación de las palabras ${ }^{6}$ ) y temático donde la semiótica jugará gran parte. Es decir, se marcarán dos directrices bien diferenciadas; por un lado las condicionantes políticas, económicas y sociales. Y por otro lado el ANÁLISIS TEXTUAL de cada uno de los elementos que entran a formar parte de la imagen.

En este preciso instante se entra a formar parte del entramado textual de la imagen. Como consecuencia actuará la Semiótica, además de tener en cuenta el entramado cultural que ayudó a formarla.

\section{Construcción del concepto fotográfico}

En alguna medida la aparición de la fotografía libró al resto de las artes de aquella obsesión por representar y retratar la realidad tal y como la veían los sentidos. Es entonces cuando las artes dan un giro y cambio de concepción. Ya que si se deseaba realismo puro, se tenía, era absurdo pues continuar con este ejercicio. Fue entonces cuando la tendencia hacia la mímesis sería tremendamente cuestionada por la aparición de ésta.

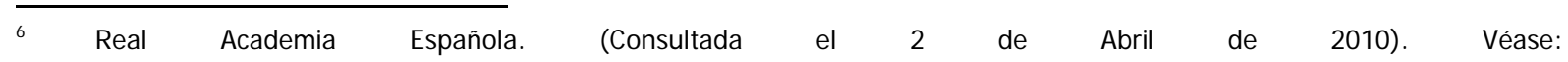
http://buscon.rae.es/drael/SrvltConsulta?TIPO BUS=3\&LEMA=semántico 
Si se observa cómo y de qué modo ha sido la trayectoria del arte ya desde antaño, se podrá observar como la tendencia a la imitación ha sido siempre constante. En el Renacimiento se aprecia las posibilidades que brinda la cámara obscura y con ella se ayuda a la creación pictórica fielmente representada (tal y como lo reflejaba la naturaleza). Y más adelante la tendencia a lo figurativa, se podría admitir, que se dio hasta la aparición de la primera imagen fijada en un soporte físico.

Hoy, y ya con el concepto fotográfico bien diferenciado de las artes pictóricas, debe asimilarse que cada uno de los conceptos que la fotografía maneja es relevante para hacer una consideración analítica del verdadero significado de la imagen. Desde el encuadre, el fondo, color, tono, iluminación, elementos discordantes, hasta el propio contacto visual serán fundamentales para hacer una descripción u otra. Y porque la misma disposición de los elementos, aun siendo los mismos que otra fotografía tendrían otro significado. Y la fotografía siempre representará una elección del punto de vista.

El fotógrafo además deberá tomar una serie de decisiones desde el preciso instante que decide capturar imágenes; se dará una exclusión de tonalidades, tal vez de zonas claras o zonas oscuras sin detalle, tal vez discriminando elementos relevantes. Pero es por ello que el fotógrafo decidirá, y cada decisión implica una renuncia. Así que fotografiar es en sí mismo un acto de interpretación.

Es interesantísima una apreciación que aparece en la revista Cinéthique en 1971 titulado Cinéma: Effets ideologiques produits par l'appareil de base ${ }^{7}$ donde se afirma que la técnica no es nada imparcial, sino más bien estrechamente ligada a una verdadera ideología. Esta implicará una cierta tendencia al espacio convencional y siguiendo la línea renacentista de la perspectiva.

\footnotetext{
${ }^{7}$ BAUDRY, J.L (1980): “Cinéma: Effets ideologiques produits par /'appareil de base" en Revista Cinéthique. Número 7/8. París. 1980. Págs. 1-8.
} 
La semiología francesa con Roland Barthes se ha encargado de analizar el discurso fotográfico desde una perspectiva estructuralista, es decir considerando el conjunto de elementos que configuran la imagen fotográfica como un sistema o estructura de interrelaciones.

Barthes es uno de los pioneros en el estudio de la imagen fotográfica y ferviente examinador de la imagen visual. Su metodología parte precisamente de esta necesidad de análisis, y en concreto se centra en la fotografía de prensa donde afirma que jamás puede dejar de considerarse cualquiera de los elementos que entran a formar parte de la misma. No puede considerarse una estructura independiente 0 aislada, sino que más bien debe contener una importante relación con el pie de foto, con el titular, con el artículo que le acompaña.

Este mismo concepto no difiere demasiado de la relación que podría desempeñar los elementos referenciales de un tipo de fotografía como pueda ser por ejemplo la artística. Pero seguramente el resultado del análisis o la connotación del mensaje visual, no sea más que el producto de unos valores añadidos, aprendidos, determinados por la sociedad económica y política que nos circunda, es decir completamente cultural.

La importantísima aportación que realizó la Semiótica, tras la superación del estructuralismo clásico, animó a gran parte de la comunidad científica al estudio y análisis del mensaje fotográfico.

Joan $\operatorname{Costa}^{8}$ propone un elenco completo de los signos que nos puede ofrecer la disciplina fotográfica, donde deja bien patente que esta no pretende jamás convertirse en un mecanismo reproductor de la realidad, sino más bien un constructor de imágenes icónicas que se forman a partir de conceptos físicos y

8 COSTA, J.: Catedrático de Diseño y Comunicación Visual, Universidad Iberoamericana de Puebla, México. Funda en 1975 y preside la Consultoría en Imagen y Comunicación (CIAC International). Escritor de infinidad de libros entre los que destacan $L a$ Imagen y el impacto psico-visualy La Identidad Visual. 
químicos, y en sintonía con la luz. Este listado está compuesto por SIGNOS

\section{LITERALES y SIGNOS ABSTRACTOS.}

Los literales serían los semejantes con el referente, y los abstractos los no analógicos. En concreto nos vamos a quedar con los ABSTRACTOS, donde se distinguen ${ }^{9}$ :

- Signos Ópticos: Flou, desenfoques, fotomontajes, repeticiones de imágenes, deformaciones...

- Signos Lumínicos: halos de luz, estrellas que se forman en la imagen por la entrada de luz en el objetivo...

- Signos Cinéticos: Estelas, barridos en la imagen, movimientos congelados, ritmos de líneas...

- Signos Químicos: Solarización, virados, imagen en negativo, exclusión de tonos intermedios, modificaciones de color...

En esta clasificación Costa mezcla tanto conceptos técnicos como estéticos (en la recepción del mensaje visual). Esto puede ocasionar un problema en el sentido que no se establece ninguna frontera divisoria entre la parte material de la fotografía y el simple hecho fotográfico o experiencia visual.

Por lo que se plantea una nueva visión mucho más amplia de las posibilidades que nos podría ofrecer la cámara fotográfica. No podemos quedarnos anclados en el pasado y observando lo que permanece simplemente en la superficie de la imagen. Susan Sontag hacía una alusión a esto mismo afirmando que La humanidad sigue irremisiblemente aprisionada en la caverna platónica, siempre regodeándose en meras imágenes de la verdad ${ }^{10}$.

\footnotetext{
${ }^{9}$ COSTA, J.: El lenguaje fotográfico. Barcelona, I bérico Europeo de Ediciones, 1977.

10 SONTAG, Susan (2006): Sobre la fotografía. Traducción de Carlos Gardini y revisado por Aurelio Major. Alfaguara. Madrid.
} 
La cultura de masas nos está educando a crear mensajes no escritos con palabras y sí con iconos visuales llenos de representación. Todo esto supone una educación constante y saber decodificar lo implícito, es la ardua tarea que hoy en día nos toca más de cerca.

En el momento de entendimiento absoluto de la imagen deberíamos reconocer varios estados; el STUDIUM y el PUNCTUM ${ }^{11}$. Esta distinción que realiza R. Barthes implica varios estados del espectador fotográfico; El primero (Studium) se referirá a reconocer la intención del fotógrafo, el objetivo de sus imágenes y como consecuencia entrar en armonía con sus ideas profundas, pudiendo estar de acuerdo o en desacuerdo. Lo importante es emitir juicios de tu reflexión obtenida y a mayor educación visual, mayor capacidad de abstracción. El Punctum por el contrario será bastante más complicado de definir. Estará relacionado con el factor sorpresa, con la fascinación que suscita una imagen al ser observada.

En el momento de fotografiar lo que estamos haciendo verdaderamente es actuar sobre dos elementos fundamentales; el tiempo y el espacio. Somos capaces de frenar el instante temporal además de la definición del espacio retratado. Siendo una concepción un tanto abstracta, resulta de una evidencia total esta definición. Por ello es que la temporalidad en la fotografía adquirirá un carácter diverso al cronológico.

\section{Análisis metodológico para el estudio de la Fotografía}

Pocos son los estudios realizados en el campo de la fotografía, pero mucho menos relacionados con el análisis de la imagen. A diferencia del cine o del arte pictórico donde sí que se ha observado una cierta tendencia a la investigación, debido en gran medida a la situación marginal que históricamente ésta ha vivido.

\footnotetext{
11 BARTHES, Roland (2004): La cámara lúcida: nota sobre la fotografía. Traducción de Joaquín Sala-Sanahuja. Paidós Ibérica. Barcelona.
} 
Sin duda uno de los esquemas de comunicación más conocidos ha sido el de Laswell, donde se observa una aproximación interesante de los elementos influyentes ya no sólo de la Fotografía propiamente dicha sino cualquier disciplina artística digna de ser apreciada. En este esquema se pueden apreciar varios elementos básicos;

- Emisor: lo denominará POLO PRODUCTOR. Es la fuerza creadora, el autor material de los hechos, es decir el Fotógrafo.

- Mensaje: se referirá al TEXTO VISUAL o FOTOGRÁFICO. Será todo aquello que queremos contar.

- Receptor: quién recibe el mensaje; el PÚBLICO OBSERVADOR o POLO RECEPTOR.

- Canal: En el caso de la fotografía difiere tantísimo que no podríamos centrarnos en un solo canal. Podría ser desde una valla publicitaria a una revista de moda, pasando por una galería de arte, en una camiseta, etcétera...

- Contexto social, histórico o cultural: No se trata propiamente de de un elemento, pero es de crucial importancia y a tener en cuenta en nuestro análisis. Influirá de modo determinante e irá desde la propia producción de la imagen fotográfica hasta la recepción de esta.

Véase: 
Proceso comunicativo

Entramado social. histórico o cultural

(1)
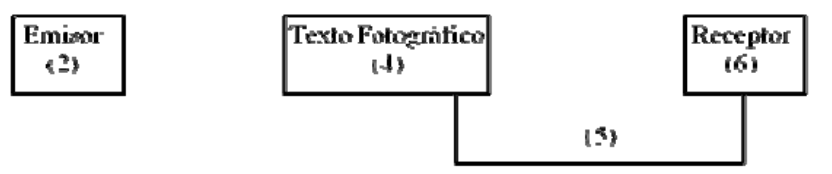

Canal

(3)

Entonces si comenzamos hablando de Texto Fotográfico lo primero que tenemos que tener en cuenta es la apreciación semiótica que ya hacemos a priori. Por lo que por ejemplo podríamos hacer un análisis de la imagen fotográfica atendiendo primeramente al Aspecto contextual sociológico, histórico y cultural, ofreciendo una visión referida a la historia, a la cultura o a los aspectos sociológicos de la imagen. 0 por el contrario podríamos centrarnos únicamente en el canal de distribución de la imagen, o en el emisor o autor ofreciendo un análisis biográfico, psicológico,...Si nos centrásemos en el texto fotográfico y la reacción del observador entones estaríamos hablando del mensaje semiótico, por lo tanto sería un análisis semiótico. Siendo éste precisamente donde nos centraremos en este ejercicio de investigación.

Es muy importante que se tenga en consideración que la naturaleza del arte y la naturaleza del fotógrafo creador son una misma unidad y donde jamás podría concebirse una separación de conceptos. Por ello es que deberemos tener en cuenta quién es el creador de la obra, para así estimar un análisis veraz de la obra. 0 también viceversa; podremos conocer a través de la obra fotográfica cómo es el autor, e incluso hacer un retrato psicológico del mismo. Pero más importante es no olvidar que desde un punto político la fotografía ha supuesto toda una revolución y concepción del arte. 
Otro de los aspectos relevantes a tener en consideración sería el eterno debate surgido entre pintura y fotografía, sobre quién se comporta con mayor rigor artístico. En realidad esto viene a cuestionar la inclusión de la fotografía en las esferas del arte.

Esta aún está por resolver, pero según añade Gisèle Freund, los verdaderos interesados en que la fotografía fuese un arte, fueron los que la querían transformar en un objeto de negocio. ${ }^{12}$

Pero si algo positivo posee la fotografía, entendido como objeto material, es la capacidad anexionadora de grupos sociales, comportándose como testimonio fidedigno de culturas. $Y$ sin embargo hay quien afirma que es "arte medio" aunque no con carácter peyorativo, sino más bien entendido como una actividad que se posiciona entre lo "vulgar" y lo "noble", que puede ser analizado desde una perspectiva estética y que dependerá totalmente de la interpretación libre de quien la observa. Pero para ser entendido de mejor modo; "medio" desde que el perfil social en una Francia situada en los 60' abarcase una popularidad de este medio fotográfico en torno al sexo masculino, con edades comprendidas entre los treinta y cuarenta y cinco años, de formación y educación media. $Y$ es por esto por lo que Antoni Estrade considera un arte "medio". Nunca con ánimo de ofender.

Y para entender como otras metodologías de trabajo en otras disciplinas muy diferentes han utilizado el medio fotográfico, Juan Naranjo ${ }^{13}$ relaciona la fotografía con la antropología, ofreciendo un interesante testimonio de la utilidad de este medio para poder entender a otras culturas y su comportamiento.

Es innegable por ello el verdadero valor antropológico de las imágenes.

\footnotetext{
${ }^{12}$ BENJ AMIN, Walter (2007): Sobre la Fotografía. Edición y traducción de José Muñoz Millanes. Pretextos. Valencia. Págs. 78 y 79.

${ }^{13}$ NARANJ O, J (2006): Fotografía, antropología y colonialismo (1845-2006). Gustavo Gili. Barcelona.
} 
Y otro de los aspectos a tener en cuenta a la hora de hacer un análisis de la fotografía expuesta sería tener en consideración el tipo de formato y técnicas fotográficas. Realizar complicadísimas sesiones fotográficas donde se precise de cámaras de gran formato por ejemplo, tendrá más complicación y mayor grado de previsión debido al peso de la cámara, que los realizados por fotógrafos que posean cámara de $35 \mathrm{~mm}$, donde la disposición a capturar momentos con estas resultan mucho más espontáneos y sin demasiada dificultad añadida.

Pero también deberemos tener en cuenta el uso de película, si es blanco y negro o color, el tipo de textura que ofrecerá según la sensibilidad, etcétera...

\section{Análisis de la Fotografía desde la Psicología}

La importancia de la psicología y la gran ventaja que irá adquiriendo con respecto a otras disciplinas humanas, hará de esta una de las más importantes aportaciones que se fueron ofreciendo a las metodologías de análisis de las artes ya desde todo el siglo XIX, y en concreto a la relación que existe entre objeto y sujeto.

Somos lo que percibimos, y por percepción entendemos la suma de todos aquellos elementos que se asocian para crear sensaciones e imágenes. Es decir podríamos considerarlo como un proceso pasivo. Sin embargo la Teoría de la Gestalt se opone a este punto de vista considerándolo completamente activo. Por lo que el ser humano cuando percibe una imagen fotográfica lo que resulta es la captación de las características de la propia imagen.

Entonces se podría afirmar con rotundidad que cuando nos sentimos apasionados por una obra fotográfica determinada, no debemos pensar que se debe a nuestra propia sensibilidad sino a la propia composición y estructura de la imagen; disposición de los elementos por ejemplo. Todo ello conformará un sistema que provocará en el espectador cierta sensación de armonía. 
La propia Teoría de la Gestalt ha considerado una serie de reglas que apoyan lo sucedido cuando observamos estas imágenes:

- Ley de Figura y Fondo: Tendemos a percibir de manera selectiva todos aquellos espacios que difieren por forma, color, tamaño,...

- Ley de Simplicidad: Lo simple verso lo complicado suele aparecer en nuestra percepción como algo bastante evidente y sin lugar a confusión.

- Ley de la Experiencia: Si reconocemos lo sucedido o acontecido en las imágenes, del mismo modo nuestro sistema perceptivo activa una alarma de aviso.

- Ley de la Forma: Reconoceremos de modo absoluto las formas frente a los colores.

- Ley de la Forma completa: Nuestro sistema cognitivo tenderá a completar la totalidad de las partes con el fin de confeccionar precisamente una unidad. También tenderemos a configurar las formas simétricas.

Para la Gestalt todo lo que perciban nuestros sentidos cobrarán un valor de unidad y cualquier pequeña modificación de los elementos, formas, etcétera...se considerará una nueva unidad, ya que esta afectará a todo el conjunto.

Como personalidades importantes consideradas en la Gestalt nos encontramos con Rudolf estilos artísticos, a un lado encontraríamos el arte más abstracto y en el otro extremo el más figurativo o naturalista. En el medio cada uno de los estilos que conforman el entramado creativo. Porque verdaderamente se centrará en la composición llena de significado y no en el debate Forma-Contenido. Pero además confeccionará un listado de las más importantes categorías que forman parte de la composición: Forma, color, luz, movimiento,... 
El psicoanálisis de Sigmund Freud también se encargará de la tarea de análisis de las obras de arte, no siendo menos el traslado a la fotografía.

Analizar la figura del autor-creador o artista y el arte como estructura simbólica ayudarán a poseer una lectura muy diversa pero apasionante. Viniendo a decir que tanto la obra artística como la personalidad creadora poseen estructuras comunes que se manifiestan en el inconsciente, ya que siempre se afirmó que la acción creadora de arte ayudaría a la liberación de nuestras fantasías.

Freud contó con enormes seguidores, pero varias fueron los caminos que fueron adoptando unos y otros: por un lado los que estudiaban la biografía desde un punto de vista psicoanalítico, por otro los que creían en la obra de arte como estructura simbólica similar a los lenguajes oníricos.

Pero hay que tener en cuenta que para Freud el ICONO ha sido lo más relevante, y el carácter simbólico se referirá tanto a los contenidos, forma y estilo. Es decir que desde un punto de vista psicoanalítico las imágenes fotográficas que manejemos, poseerán una iconología que afectará al significado, al género y al modo de construirlas.

Dejando aparte los puntos de vista psicológicos, es necesario también hablar del método iconológico. En este enfoque se propone una teoría donde se apuesta por el arte como elemento psicológico de cualquier época. En este método se habla de una relación estrecha entre la forma y el contenido, ofreciendo un símbolo como producto que representa el arte y la cultura de la misma.

De este enfoque encontramos como máxima autoridad a Erwin Panofsky. Se planteará cómo y de qué manera se llego a construir la perspectiva renacentista, la representación espacial que supuso y cómo transmite la idea de una sociedad que no pensó en esta como una realidad objetiva. Es decir; Relativismo cultural. 
Panofsky aboga por construcciones concebidas por cada cultura y su modo de observar el mundo, más que estructuras visuales objetivas, Resulta interesante ya que de algún modo no encontramos una cultura universal o general que llegue a todos, pensamos en herramientas culturales, seguramente comprensibles en mayor grado por los componentes de los mismos pueblos. Esto de alguna manera, hace que la fotografía encuentre su sitio precisamente en donde nació. A pesar de que convivimos con una educación visual importante, Oriente y Occidente aún conservan puntos de vista completamente incomprensibles los unos de los otros, conservando y aportando a las esferas más novedosas de la Fotografía de esa espontaneidad y frescura que en ocasiones se demanda. Véase Hiroshi Sijimoto. ${ }^{14}$

Panofsky nos define su método de análisis de la siguiente manera:

10) Previo análisis iconográfico de las estructuras o elementos que aparecen en la imagen fotográfica, donde se puede observar cuál es la primera significación de los iconos.

20) Se procederá al verdadero análisis iconográfico donde localizaremos las historias o significados contenidos en los iconos de la imagen.

30) Se considerará el análisis iconológico como el verdadero fin de los análisis de obras de arte.

Es necesario aclarar la diferenciación de significado entre análisis iconológico y análisis iconográfico; El iconográfico es un análisis descriptivo y el iconológico es más interpretativo. Entonces por ello la comprensión de una imagen fotográfica será un acto de interpretación. 


\section{Perspectiva Semiótica de la Fotografía}

Podemos observar como desde principios del siglo XX se ha notado cierta tendencia en las metodologías de trabajo a encontrar la verdadera significación que poseían los lenguajes artísticos y los medios de comunicación de masas, con cierta tendencia a explicar algo más que lo percibido por los sentidos.

Sin embargo se debía partir de sistemas o estructuras ya estudiadas y asimiladas por los estudiosos además de los espectadores, por ello se toma como punto de partida la Lingüística por ser un sistema de comunicación de los seres, aunque la verdadera novedad residirá en los signos no lingüísticos pero iconos comunicadores.

Ferdinand de Saussure a través de su Curso de Lingüística General ${ }^{15}$ se estrena como principal referente de la teoría Semiótica. Considera el lenguaje como un conjunto de signos conformados de modo científico y que entremezclan entre sí para dar lugar a significados concretos.

En él se encontrará un principio fundamental; el Signo. Éste poseerá dos puntos de vista que se asociarán entre sí y que se denominará SIGNIFICANTE (EI plano de la Expresión) y el SIGNIFICADO (Plano del Contenido). La imagen fotográfica entendida como obra de arte, si la concibiésemos desde la perspectiva semiótica, conformará una Totalidad significante que será el resultado de la suma y relación de todos los elementos que aparecen en la misma.

Otro de los precursores del pensamiento semiótico podría ser Charles S. Pierce, aunque bastante más complejo que el anterior, define el SIGNO como un referente. Es decir una entidad que se sustituye. $Y$ el INTERPRETANTE que es el elemento que relaciona el signo con su objeto. 
En su teoría semiótica define tres tipos de signos:

- ICONOS: Signos que son similares al objeto.

- ÍNDICES: Relaciona el signo con el objeto.

- SÍMBOLOS: Signos que representan un conjunto de normas elaboradas por consenso. Por ejemplo los lenguajes naturales.

Pero no es hasta la aparición de Charles Morris cuando se da una verdadera aproximación de los lenguajes codificados al campo de la estética. Distinguirá dos tipos de signos en el discurso artístico:

- SIGNOS ICÓNICOS: Son las fotografías, las representaciones.

- SIGNOS NO ICÓNICOS: Son los signos lingüísticos.

Porque como ya bien sabemos el fin artístico residirá en la construcción de signos icónicos que signifiquen realidades. De este modo la obra artística será capaz de comunicar de modo sutil el mensaje que su creador concibió durante el proceso creador.

Es importante no dejar de mencionar la aparición de dos corrientes surgidas a principios del siglo XX que resultaron oponerse a las tradicionales teorías de las obras de arte conocidas hasta el momento; Formalismo y Estructuralismo. El formalismo ruso propone un momento transgresor y rompedor en toda la obra de todo artista que pretenda convertirse en personalidad relevante. R. Jackobson además de pasar por su época formalista, alcanzó importancia con los estructuralistas franceses de los $50^{\prime}$, aunque lo verdaderamente novedoso de él fue su formulación de las funciones del lenguaje (referencial, fática, conativa, metalingüística, emotiva y poética). Pues será en la última, la función POÉTICA, la interesante desde el punto de vista semiótico en el análisis y entendimiento de las 
obras de arte. Ésta se centrará en la forma en que son producidas las expresiones del lenguaje. Ahora bien, si nuestro lenguaje no está configurado a través de signos, reglas gramaticales, etcétera...pero deseamos llevarla al terreno de las artes, entonces debemos abstraer esta concepción para transformar el lenguaje de signos en lenguajes artísticos, y después observar el mecanismo de construcción de la belleza. De este modo observaremos como existe cierta tendencia a la ambigüedad y auto-reflexión del mensaje.

En el caso de las artes se nos permite cierta libertad y no ser tan rigurosos en las formas de expresión, ya que de algún modo los mensajes artístico deben ser connotativos y los científicos denotativos. En el primero se admite la ambigüedad mientras que en el segundo jamás deberemos construir mensajes que sean incomprensibles o confusos para una comunidad científica deseosa del saber. Las artes son impredecibles, aunque quisiéramos materializar reglas de expresión posiblemente no lo conseguiríamos, y básicamente por su origen ubicado en las pasiones de los creadores y los observadores.

Pero a grandes rasgos, la importancia de Jackobson fue encontrar ese paralelismo entre la lingüística y las artes, y por ello entendido este como posible fenómeno semiótico, por lo tanto susceptible de ser estudiado como si de un lenguaje se tratase.

El antropólogo Levi-Strauss y Jackobson hacen un bello paralelismo entre la estructura de la obra de arte y un la estructura interna de un cristal, donde la función del semiótico sería encontrar las propiedades implícitas, mientras que el químico buscaría lo mismo pero en su laboratorio de trabajo.

El Estructuralismo representa la obra de arte no como un sistema de códigos individuales, sino más bien colectivo. Pero es que además el observador de la obra de arte, de la imagen fotográfica,... ya dispone de una educación visual determinada 
y pronta para mirar a esta, además de entender el mensaje de un modo tan avanzado que lo que hace es considerar una estrecha relación entre la persona que observa y el objeto observado.

Pero es necesario que el observador, si desea entender la obra, conciba la imagen fotográfica como si de un signo (Representación) de cierta intencionalidad se tratase.

Esta semiótica estructural que encuentra en la década de los $70^{\prime}$ y $60^{\prime}$ posiblemente el mayor número de estudios referidos a las artes y la literatura, encuentra en Roland Barthes uno de sus más grandes exponentes. Pero son muchísimos más; A. J. Greimas, J. Kristeva, Levi- Strauss, ,... todos ellos consideran las obras artísticas como verdaderos enunciados narrativos, donde coexisten diferentes elementos que componen una unidad insertada en una cultura determinada.

El Grupo $\boldsymbol{\mu}$ [Me], escuela semiótica belga, tal vez sea la aproximación más fidedigna en cuanto a estudios de retórica de la imagen se refiere. Parten de la semántica estructural de Greimas para llegar finalmente a construir una retórica general ${ }^{16}$. Sin embargo se van a encontrar con grandes dificultades como la crítica de arte que pretenderá centrar toda su energía en confeccionar enunciados particulares, y la Lingüística intentando imponer la oposición entre lengua y comunicación visual.

Los componentes del Grupo $\mu[\mathrm{Me}$ ] consideran que las imágenes se comportan como verdaderas estructuras significativas pero que deberían ser estudiadas por modelos semióticos que pudieran considerar así la organización interna que poseen.

La teoría semiótica de Umberto Eco es uno de los enfoques con más repercusión mediática, además de considerarse base fundamental de la semiótica general.

${ }^{16}$ GROUPE [M] (1987): Retórica General. Paidós Ibérica. Barcelona. 
Consistirá en oponer la posición estructuralista francesa (con base en la lingüística) con el pensamiento filosófico-semiótico de Charles S. Pierce, quien considera que el signo es una síntesis visual de un objeto real que ha sido transformado. Si se da esto, entonces de alguna manera estamos ofreciendo mayor protagonismo en el proceso semiótico al observador de lo que antes tenía.

Pero Eco también se apoyo en la Escuela Soviética, quien por ejemplo adoptó la Semiótica de la cultura, es decir considerar la semiótica como un modelo interpretativo de la realidad, donde se considera que cualquier acontecimiento cultural posee un componente de comunicación. Por lo tanto la cultura entera se percibirá como un sistema lingüístico, con sus signos, códigos y cuya finalidad sea la de comunicar. Por lo tanto el arte fotográfico también se comportará como un proceso comunicativo, siendo analizado a su vez como un lenguaje cualquiera.

Si deseásemos elaborar herramientas que nos ayudasen al análisis de los mensajes fotográficos, probablemente ahondaríamos en el pensamiento de Eco de nuevo. Le interesa la semiótica comunicacional donde se confeccionan teorías de la producción de signos, pero también la semiótica de la significación que producirá teorías de los códigos. Por lo tanto:

- Semiótica de la Comunicación $\rightarrow$ Teorías de la Producción de signos.

- Semiótica de la Significación $\rightarrow$ Teorías de los códigos.

Y tanto en cuanto a los estudios semióticos que se han realizado tomando como punto de partida la Fotografía, podríamos decir que la Semiótica General considera que la imagen Fotográfica por supuesto que se comporta como un sistema lingüístico donde además aparecen códigos con significación relevante y relativa al mensaje final, pero considerando la interpretación abierta y libre. 
Marine July escribió cómo y de qué manera el método semiótico era necesario para el análisis de la imagen fotográfica mostrando estudios de los signos icónicos (figuras y motivos), colores, formas, texturas, espacios,...Además considerando de manera precisa la necesidad de distinción entre "observación" e "interpretación", ya que es primordial la interacción entre "observador" y "objeto observado".

\section{Fotografía y Adjetivo. Máxima expresión visual}

Es interesante trascender el mensaje adjetival a un plano visual claro, por lo que tal vez un análisis más exhaustivo del adjetivo, permitirá que el lector revise cualquier duda gramatical o cuestión lingüística. Para realizar esta operación interesa destacar una aportación que consiste ante todo en subrayar el maravilloso trabajo realizado por Leonardo Gómez Torrego en su Gramática Didáctica del Españo ${ }^{77}$ y en concreto en la sección que recoge el adjetivo, sus variantes y excepciones, además de su tipología.

Además de la excelente tarea que desempeña el adjetivo de “acompañar al sustantivo, sea o no concreto, sean o no abstracta. Que especifica características, que se obtendrá como adyacente y coincidirá en género y número. Que admitirá afijos y morfemas de grado superlativo. Que definirá una descripción y se le sumarán el carácter comparativo, de superioridad, de inferioridad...Aquel que sirve como instrumento para designar a nuestra obra poética creadora, que estimulará nuestro intelecto para redefinir obras externas y creaciones que nos conmueven con un solo fin; materializará lo que invade nuestro pensamiento al enfrentarse a un discurso",

\footnotetext{
${ }^{17}$ GÓMEZ TORREGO, Leonardo (2010): Gramática Didáctica del Español. Ediciones SM. Madrid.
} 
es necesario entender, y esta vez de un modo mucho más formal y explícito donde la precisión y la determinación harán entender a nuestros "deseosos" lectores, como la forma ayuda a crear un fondo con poder, impacto y lleno de sensaciones provenientes del intelecto y rozando el sentimiento.

El adjetivo se presenta de un modo muy particular; siempre expuesto como palabra tónica y siempre dispuesto a agregar o adicionar cualquiera que aparezca o se cree en la lengua.

Reitero su énfasis en tomar prestado el género y número de los sustantivos que le preceden o prosigan, con el fin de no descuidar la concordancia que tanto le caracteriza. Por ello es que distinguiremos dos tipos:

a) Adjetivos de una sola terminación; (Invariables en género) Jamás se observará el género porque sólo cuentan con uno (Rojo, verde, azul,...breve, débil, ágil,...)

b) Adjetivos de dos terminaciones; (Variables en género) Diferencian el género mediante las terminaciones (bello/a, guapo/a, sucio/a,...)

El número también se designa a través de la terminación y en ocasiones es invariable ya que al no tratarse de palabras agudas, se mantienen invariables (un triángulo isósceles/dos triángulos isósceles, una entrada gratis/dos entradas gratis,...).

Jamás serán acompañados de determinativos y si así es, entonces hablamos de sustantivados.

Existirán adjetivos que admitan cuantificadores pero deberán ser combinadas con las formas apocopadas adverbiales "tan, cuan, cuán, muy" (¡tan gracioso!, ¡cuán bello!, ¡muy hermoso!). Por ello es por lo que jamás podrá exhibirse o presentarse con las 
formas plenas tanto, cuanto, cuánto y mucho. Y si así fuese, la razón sería por la sustantivación (Tanto gracioso no es bueno!, Cuanto necio se percibe!).

Con respecto al adjetivo existen muchísimos tópicos que deberían ser revisados, como bien afirma Gómez Torrego en su Gramática didáctica del Español. Una de ellas y la más popular, tradicionalmente hablando, sería la de afirmar que "es la única palabra que expresa cualidad". Realmente no es así, ya que el sustantivo también expresa cualidad (Maldad, fealdad, virtud,...). Por lo que además se aclara que no sólo expresa cualidad sino también estados, relaciones,...

La tipología que manejaremos del adjetivo, y según su significado, estará dividido en:

1) Adjetivos CALIFICATIVOS: Expresan cualidad del sustantivo.

2) Adjetivos DE PERTENECIA: Lingüístico, social, musical,...

3) Adjetivos GENTILICIOS: Expresan el origen o procedencia.

4) Adjetivos CUASIDETERMINATIVOS: Su significado está cerca al de los determinativos (Siguiente, último, anterior, posterior)

Por lo que el planteamiento irá más allá de lo hasta ahora conocido. En resumen se puede decir que para poder entender este ejercicio de investigación y posible cambio de concepción en la creación artística de contenidos visuales formalizados a través de la fotografía, se debería partir del lenguaje, del proceso que lleva a cabo para confeccionar un mensaje poético, de los elementos que forman parte de éste y de la distribución estratégica que deben seguir si quieren regirse por este protocolo de actuación con fines poéticos. 
Una vez dado este paso, el siguiente paso sería dar un salto a la fotografía, adaptar lo que el lenguaje hace para la obtención poética, llevarlo a la imagen fotográfica y observar si siguiendo las mismas reglas se consiguen los mismos resultados.

\section{Fotografía y PhotoEspaña. Organismo referencial}

PhotoEspaña es un organismo ya casi convertido en institución de referencia para todo fotógrafo que dedique su actividad visual hacia un nuevo horizonte artístico, pero que utilice la fotografía como herramienta expositiva de acontecimientos reales o irreales, con fines sociales, reivindicativos, antropológicos, etcétera... pero siempre bajo un marco estético muy definido y profundo.

Además constituye una oportunidad para miles de artistas que pretenden hacer descubrir la verdadera esencia de su obra creadora gracias al festival que convocan todos los años durante los meses de Junio y Julio ya desde el año 1998. Hoy por hoy, y tras un ingreso humilde en nuestra sociedad, constituye uno de los referentes mundiales de la fotografía, siendo cita obligada de todo aquel que desee renovar todo su conocimiento y bagaje fotográfico hasta el momento conocido, y significando un verdadero privilegio contar con un organismo nacional que influya en todo el mundo.

Cuenta con varias localizaciones y sedes principales en toda España y en Europa, y sus exhibiciones son presentadas en infinidad de museos, galerías de arte, fundaciones, convirtiéndose de este modo en el festival más atractivo de los celebrados en España y que llegan a figurar más de medio millón de visitantes.

Con respecto a ese componente de "oportunidad" que se citaba anteriormente, se podría decir que en cada edición del festival se da una temática bien definida, ya configurada y especificada en las bases de la categoría en la que se participe. Y siendo ya más de seiscientas las exposiciones organizadas en los museos más 
prestigiosos de la ciudad como Casa de América, Museo Nacional Reina Sofía, centro cultural Bellas Artes, Thyssen-Bornemisza, e incluso en el Museo del Prado.

Por ello es que se toman como ejemplo sus premiados de la última década, y se analizan sus discursos visuales, creyendo que tal vez aparezcan esos elementos adjetivados de los que previamente se hablaba. Desde Chema Madoz a Malick Sidibé (2000 a 2009 inclusive), serán los fotógrafos que se analizarán.

\section{Conclusiones}

En este apartado conviene dejar bien asentada el concepto "Hipótesis = Resultado", por lo que es crucial que se muestre la premisa que se planteó en un principio y darla visibilidad, para de este modo poder partir de donde nació la idea.

- "El adjetivo es el eslabón desencadenante para la creación y confección de significado poético dentro del lenguaje fotográfico".

Según los experimentos que se realizaron, se constata que hay una cierta tendencia a que se verifique la primera de las hipótesis en cuanto a que en el propio discurso analítico (del estudiante "desconocedor" de la posibilidad del recurso estilístico dentro de la imagen fotográfica de la última década) en el momento que destapa el contenido implícito, vierte una tendencia adjetival que tratará de explicar el significado de la imagen, desentramando además cada uno de los elementos que influirán en una determinada lectura dando así una figura u otra.

El adjetivo, por el momento, consigue acercarnos a una futura respuesta similar en forma de figura.

Prueba de ello es que en los cuatro experimentos realizados, además de constatarse mayor o menor afluencia o frecuencia del adjetivo en el discurso lingüístico, se puede 
observar que incluso existe una denominación directa en relación con el propio nombramiento de la figura directamente.

Para hacer constatar y verificar la hipótesis planteada es necesario observar los resultados de los test realizados. Siendo éstos:

Gráfico no 1: Tabla de Resultados

\begin{tabular}{|l|c|c|c|c|}
\hline \multicolumn{1}{|c|}{ Alumnos } & Publicidad & Arquitectura & Artes & Doctorado \\
\hline Encuestados & 19 & 3 & 10 & 8 \\
\hline Adjetivo & 1091 & 118 & 648 & 404 \\
\hline Media alumno/Adjetivo & 57,42 & 39,3 & 64,8 & 50,5 \\
\hline
\end{tabular}

Fuente: Resultados obtenidos de la totalidad de alumnos que se enfrentaron al análisis de contenidos. Perteneciente a los trabajos de campo realizados para la investigación "El Adjetivo visual. De la figura Retórica al significado de la imagen fotográfica". Hernando Gómez.

En esta primera aproximación a un análisis cuantitativo se puede observar cuáles son los datos más numerosos en cuanto a la presencia del adjetivo en el discurso elaborado frente a las imágenes se refiere. Se destaca que los discursos más numerosos, en cuanto a adjetivación, han sido los alumnos del primer año de Bellas Artes con un promedio de 64,8 adjetivos en cada Test, frente a los estudiantes de Arquitectura que han sido superados en 25,5 adjetivos.

Sin embargo no han sido presentados los datos en promedios generales, siendo éstos:

Gráfico no 2: Presencia total del Adjetivo

\section{F(c)tak Alituriros Encuestados}

Adjetivos 4n:

2261 
En este caso el dato sería más significativo aún; la media ponderada de frecuencia del adjetivo en el discurso de la totalidad de alumnos sería 56,52 adjetivos por test realizado, queriendo significar o dejando entrever que:

1- Los alumnos de Bellas Artes destacan en 8,28 adjetivos más que la media.

2- Los alumnos de Arquitectura se sitúan en 17,22 adjetivos por debajo de la media.

3- Los alumnos de Doctorado se sitúan en 6,02 adjetivos por debajo de la media.

4- Los alumnos de Publicidad y RR.PP superan en 0,89 adjetivos a la media ponderada. Siendo además el grupo que más cercano se encuentra a la misma.

Gráfico № 3: Géneros: Media Aritmética

\begin{tabular}{|l|l|l|l|}
\hline Total Alumnos Encuestados & 40 & $\begin{array}{l}\text { Media Aritmética } \\
\text { Adj/Persona }\end{array}$ & 56,52 \\
\hline Hombres & 15 & $\begin{array}{l}\text { Media Aritmética } \\
\text { Adj/Hombre }\end{array}$ & 52,8 \\
\hline Mujeres & 25 & $\begin{array}{l}\text { Media Aritmética } \\
\text { Adj/Mujer }\end{array}$ & 58,76 \\
\hline
\end{tabular}


Lo cierto es que muchas son las preguntas e hipótesis que se plantearon en este primer acercamiento al trabajo de investigación, sin embargo es imprescindible afirmar que la presencia implícita de una figura retórica es la mayor constante que se ha podido apreciar en la mayoría de los discursos visuales analizados. Da la impresión que el recurso estilístico que ayuda a embellecer el lenguaje visual, prácticamente coexiste con el discurso o manifiesto que se extrae de las imágenes. Podríamos darnos cuenta que existe, pero no es excluyente aún sin conocerse, ya que en la totalidad de las palabras, y en concreto con la presencia del adjetivo se está diciendo mucho más allá de lo que aparentemente significan ellas mismas. La presencia de un epíteto que el observado decide incluir en su discurso, está ayudando a descifrar ese mensaje, para tal vez materializarlo en forma de METÁfORA, HIPÉRBOLE o incluso HIPERBATÓN. Por ello es que dejaremos para la continuación de este trabajo una de las labores más importantes; vinculación del adjetivo a la retórica visual.

\section{Bibliografía}

ALARCOS LLORACH, Emilio (2005): Gramática de la lengua Española. Espasa Calpe. Madrid.

ARISTÓTELES: Retórica. Introducción, Traducción y notas de Alberto Bernabé, Alianza Editorial. Madrid.

BARTHES, Roland (2004): La cámara lúcida: nota sobre la fotografía. Traducción de J oaquín Sala-Sanahuja. Paidós I bérica. Barcelona.

BASSAT, Luis: El libro rojo de la publicidad. Ediciones Folio. Barcelona. 
BENJ AMIN, Walter: Sobre la Fotografía. Edición y traducción de José Muñoz Millanes. Pretextos. Valencia

BERISTAIN, Helena (1995): Diccionario de Retórica y Poética. Porrúa. México.

BOSQUE, I gnacio (1995): Repaso de la sintaxis tradicional. Arco/Libros. Madrid.

COSTA, J. (1977): El lenguaje fotográfico. I bérico Europeo de Ediciones. Barcelona.

DELEUZE, Gilles (1971): La lógica del sentido. Editorial Barral. Barcelona.

ECO, Umberto (1989): La estructura ausente. Introducción a la semiótica. Traducción Francisco Serra Cantarell. Editorial Lúmen. Barcelona.

ECO, Umberto (1995): Tratado de la semiótica general. Traducción de Carlos Manzano. Editorial Lúmen. Barcelona.

ELIOT, Thomas (1999): Función de la Poesía y función de la crítica. Edición, traducción y prólogo de Jaime Gil Biedma. Tusquets. London.

ELIOT, Thomas (1990): On poetry and poets. Faber and Faber. London.

GARRONI, E.: Proyecto de Semiótica. Barcelona, Editorial Gustavo Gili, 1975.

GILI y GAYA, Samuel: Curso Superior de Sintaxis Española. Ediciones Biblograf. Barcelona.

GÓMEZ TORREGO, Leonardo (1998): Gramática Didáctica del Español. Editorial SM. Madrid.

GROUPE [M] (1987): Retórica General. Paidós. Barcelona.

GROUPE [M] (1993): Tratado del Signo visual: Para una retórica de la imagen. Traducción Manuel Talens Carmona. Cátedra. Madrid.

LAUSBERG, Heinrich (1993): Elementos de la Retórica literaria. Gredos. Madrid.

LAUSBERG, Heinrich (1980): Manual de Retórica. Editorial Gredos. Madrid. 
MARZAL FELICl, Javier (2010): Como se lee una fotografía. Cátedra. Madrid.

MORTARA GARAVELLI, Bice (1991): Manual de Retórica. Cátedra. Madrid.

NARANJ O, J. (2006): Fotografía, antropología y colonialismo (1845-2006). Gustavo Gili. Barcelona.

PORTA, L. La investigación cualitativa: El Análisis de Contenido investigación educativa.[Mar de Plata, Argentina]: Universidad de Mar de Plata. "Capítulo 2 El análisis de contenido". Disponible en web: www.uccor.edu.ar/paginas/REDUC/porta.pdf [Consulta: 12 de Abril 2010]

ROMERA, A. Retórica. Manual de Retórica y recursos estilísticos. Disponible en web: http://retorica.librodenotas.com/ [Consulta: 6 de Abril 2010]

SAUSSURE, Ferdinand (1945): Curso de lingüística General. Ediciones Losada. Buenos Aires, 1945.

SCHAEFFER, J.M (1990): La imagen precaria: del dispositivo fotográfico. Traducción de Dolores Jimenez. Cátedra. Madrid.

SONTAG, Susan (2006): Sobre la fotografía. Traducción de Carlos Gardini y revisado por Aurelio Major. Ediciones Alfaguara. Madrid.

TORNQUIST, J (2008): Color y Luz. Teoría y práctica. Editorial Gustavo Gili. Barcelona.

WOLFGANG VAN GOETHE, J (1999): Teoría de los colores. Valencia, Consejo General de la Arquitectura técnica de España, Valencia. 